\title{
ASSESS THE EFFECT OF SERVICE QUALITY ON CUSTOMER SATISFACTION IN FACEBOOK SOCIAL COMMERCE IN EGYPT
}

\author{
Rehab ELBadrawy, Sara ElKheshin and Nermine ELEssawy \\ Arab Academy for Science, Technology and Maritime Transport, Alexandria, Egypt
}

\begin{abstract}
The numbers of social network users are boomingas a result of increased Internet access and smartphone accessibility. Facebook in particular is considered one of the most important social networks in Egypt, where there is a noticeable increase in the preferences to shop on Facebook. This paper examines the service quality dimensions that influence customers' satisfaction and their purchase intention in the context of B2C social commerce through Facebook. The proposed model includes eight dimensions: usability, reliability, responsiveness, empathy, courtesy, trust, price, and security. The results revealed all dimensions had a positive effect on overall service quality variable which in turn positively influenced the user satisfaction which affects the purchase intentions of customers.
\end{abstract}

\section{KEYWORDS}

Electronic Service Quality, SERVQUAL, Customer Satisfaction, Social Commerce, Facebook

\section{INTRODUCTION}

Nowadays, the world witnessed a rapid growth and diffusion of information and telecommunication technologies (ICT). Most day to day activities have significantly changed as a result of using the internet. The E-commerce sector has experienced major changes brought by the technological innovations such as the social media technologies [1]. That Combined with the widespread of smartphones led to a significant increase in the number of social media users [2].

The increased use of social media has encouraged many people to set up retail businesses across social media networks [3] Known as Social commerce. Social commerce is a form of ecommerce where sellers can market and sell their products directly to customers using social network such as Facebook [4], [5]. The Internet users in Egypt reached 49.23 million. 90\% from them are Facebook users [5]. Egypt e-commerce transactions are expected to reach 2.7 billion USD by 2020 mostly paid in cash [7]. The number of retail customers in Egypt of social commerce is higher than any other online channel [6].

Many researchers have investigated the service quality dimensions in the online shopping context. With the growing competition, service quality is considered a main feature to sustain the competitive advantage and retain high customer satisfaction levels [8]. For the social commerce environment, there are few studies that examine service quality of social commerce services [58]. Although, using social media for shopping is easy and convenient, there are some barriers that may affect customers 'purchasing decision [3]. 
International Journal of Managing Information Technology (IJMIT) Vol.12, No.3, August 2020

The research question focus to identify the key factors of S-commerce service quality dimensions as perceived by s-commerce customer and this answered by investigating the service quality dimensions that influence customers' satisfaction and their purchase intention toward social commerce using Facebook. This paper is organized as follows.

Section 2 presents a review of the literature on Social commerce and service quality dimensions used in online shopping. Section 3 introduces the research methodology, the model framework and the development of the hypotheses used in this paper. Section 4 describes the sample size, and presents the results. Finally, Section 5 provides conclusions and limitations of the results.

\section{Literature REVIEW}

\subsection{Social Commerce}

Social media is considered an effective tool to socialize, share information and a new method to connect with together online [9]. The huge number of social media users encourages retailers adopt new business opportunities to market and sell their products through these networks.

In [10] social commerce was identified in three main categories. The first category is the integration of social media technologies with e-commerce websites using web 2.0 tools to help customers to share products using their accounts. The second category is the incorporation of ecommerce features in the social media platform where sellers benefit from the existing user base and popularity to sell products. Finally, the third category is the bulk-group websites where customers establish a social group based on similar interests and needs, and makes purchases for price advantages.

In Egypt, the total population exceeds 100 million citizens of which $49.23 \%$ are Internet users [6] and $40 \%$ of the total population are social media active users of which 38 million also access their accounts via mobile [6]. Facebook is considered the most popular social media used by Egyptian with 39 million users (90\% of social media users) followed YouTube (34 million users), Instagram (10 million users) [6]. According to [11], the age group 25 to 34 year olds accounts for $32.9 \%$ of Facebook users in Egypt, whereas users who are 65 years and above only counted for $1.9 \%$. The Egyptian Internet user spends up to 8 hours over the Internet, of which 3 hours on average each day is spent on social media [6].

E-commerce in Egypt is growing rapidly, the number of online shoppers increased from 15.2 million to 17.7 million, between 2015 and 2016 [12]. The most popular payment method used in the Egyptian ecommerce is cash on delivery ( $70 \%$ of purchases), followed by credit cards (16\% of purchases). In 2017, the Egyptian B2C e-commerce turnover grew by $22 \%$, reaching US\$ 5 billion [13]. However, e-commerce only accounts for $0.4 \%$ of retail sales in the country, [13].

Facebook e-commerce is defined as communities that use Facebook to get members in social media to shop online [1]. $46 \%$ of online customers use social media to make purchase decisions [14]. Mark Zuckerberg previously cited that the next explosion in e-commerce would be social commerce [15]. In Egypt, Digital marketing [16], reported that the number of Egyptian users who access shopping and fashion pages on Facebook is 19 million. Many models were applied concerning Facebook e-commerce in Egypt. The first type is Business-to-Consumer (B2C) Facebook e-commerce where sellers used Facebook features to share their products pictures on their own pages; members can immediately buy them using cash on delivery payment method. 
International Journal of Managing Information Technology (IJMIT) Vol.12, No.3, August 2020

The second type is also considered as Business to Customer (B2C) Facebook e-commerce where sellers act as intermediaries. They used Facebook features to share many brands' pictures through their pages. Members can make orders by paying a percentage of the invoice order (Cash) and the rest of payment is paid in cash upon delivery. The third type is a Consumer-to-Consumer (C2C) e-commerce where Individuals share products they wish to sell with the usage condition as new or used where the buyer and seller negotiate and agree on the price together. Among these, B2C where sellers are intermediaries is the primary focus of this research.

Social commerce has grown rapidly; thus, it has not been studied as comprehensively as ecommerce and social media. Authors and academics made some efforts in understanding why customers use social media. They stated in [17] assess the characteristics of the social commerce vendor and investigates their influence on users' trust. Where the authors used the use of technology and unified technology acceptance model to test the influence of trust and the perceived usage on social commerce intent. In [18] it was applied stimulus-organism-response model to investigated the influences of social commerce sites on customers' virtual experiences and on their intentions to purchase products, the findings revealed that social presence, informational support, emotional support and affective states (familiarity and closeness have positive effects on social interactions. However, these dimensions have insignificant effects on social shopping intention.

\subsection{The SERVQUAL and E-SERVQUAL Dimensions}

With the growing competition, service quality has become a common area of research investigation, and has been known as a key aspect in maintaining competitive advantage and sustaining satisfying relationships with customers [19] and [20]. The service quality (SERVQUAL) model is defined as the relative perceptual distance between customer expectations and evaluations of the service experiences and service quality using a multi-item scale [21].

The SERVQUAL model recently has been widely used in several contexts such as banking, health, education, e-commerce, information systems, e-retailing and others [22], [23]. SERVQUAL model comprises of five dimensions of tangibles, reliability responsiveness, assurance and empathy. Researchers have criticized the value of adapting traditional SERVQUAL dimensions to suit E-service environment. Therefore, [24] provided the E-Core Service Quality (E-S-QUAL) and E-Recovery Service Quality scales (E-Rec S-QUAL scales). ESQ Instrument was established specifically to measure e-services quality, which includes four dimensions, efficiency, fulfillment, system availability, and privacy. In addition, E-Rec S-QUAL contained three dimensions, responsiveness, compensation, and contact [24].

Most of the previous researches focused on developing Service Quality scales to determine the relationship between Service Quality and other constructs like customer satisfaction, and purchase intentions. The usage of SERVQUAL dimensions differs depending on the kind of industry, and the context [26] and [27]. It was tested in [27] the relative importance of service quality dimensions in E-commerce experiences using responsiveness, empathy, tangibles and assurance dimensions.

While, [28] applied accessibility, reliability, ease of use/availability, interactivity, responsiveness/efficiency, and security/privacy dimensions to assess online customer service quality of online shopping. In [29] SERVQUAL model was applied using tangibility, reliability, responsiveness, assurance and empathy dimensions to measure online customer satisfaction package delivery services. Jiang in [30] developed a model to inspect the effect of e-service 
quality dimensions on customer-perceived value and customer loyalty using five key e-service quality dimensions, which are care, reliability, products portfolio, ease of use, and security.

They used five-dimension service quality instrument in [31] includes usability, usefulness of content, and adequacy of information, accessibility, and interaction to assess the service quality of web portals. They investigate the impacts of service quality on customer satisfaction and loyalty in e-retailing supply chain in [32] using electronic service (e-service) quality dimensions ease of use, website design, customization, responsiveness, assurance alongside logistics service quality dimensions contact quality, order release quantities, information quality, ordering procedures, order accuracy, order condition, order quality, order discrepancy handling, and timeliness. Moreover, it was suggested in [33] an extended model of service quality dimensions including reliability, responsiveness, security, access, communication, understanding the customer, credibility, tangibles, courtesy, price, competence and customization (flexibility).

Nowadays, Internet and the social media are co one considered as one of the main digital marketing tools. The analysis of customer evaluations of online shopping is a main concern for researchers and practitioners, especially in the field of e-commerce [68]. Many researches revealed that customer satisfaction are one of the main functions of perceived service quality of electronic services [69]. Previous studies found that there is a positive and significant relationship between service quality, satisfaction of customers and purchase intention [34]. They measured the service quality of $\mathrm{m}$-commerce in a commercial environment using service quality, information quality, and system quality dimensions in [35]. The overall service quality will influence customer satisfaction, which in turn will affect the purchase intention of customers.

Customer satisfaction based on the website service quality with confirmation of customer expectation was measured in [36]. The results found that website service quality has a significant and positive relationship with confirmation of customers' expectations and their satisfaction level towards online shopping. Furthermore, Rust and Zahorik [70] found that overall service quality and customer satisfaction has a significant impact on customer retention, market share, and profitability. Llusar [71] used customer satisfaction as a mediator of the relationship between firm perceived quality and customer purchase intentions.

Even though the above mentioned service quality researched in online shopping, there are few studies that examine service quality of social commerce service [58]. It was recommended a quality service model for online social commerce from customer perspective in [37] including six dimensions reliability, responsiveness, ease of use, information, trust and security. In [1] it was used Kano quality model the key service quality characteristics of community buying. The study found that key quality elements for attracting customers are price and recommendation features. [38] Used the E-service quality dimensions reliability, responsiveness, assurance, reputation and information quality to measure Customer to customer (C2C) social commerce (S-Commerce) in Thailand. The results revealed that the dimension of information quality showed the highest factor followed by reliability dimension.

\section{RESEARCH MODEL AND HYPOTHESES}

From the above-mentioned literature and taking advantage of the previously used dimensions, the proposed scale [see Figure 1] is composed of 8 dimensions: Usability, Reliability, Responsiveness, Trust, Empathy, Courtesy, Price and Security. The proposed model also examines how these dimensions affect the overall service quality, customer satisfaction and the purchase intentions. 


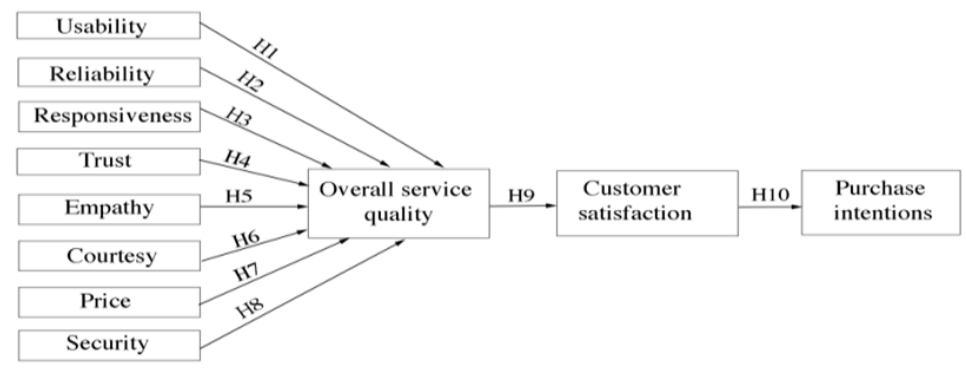

Figure1. Proposed Model of this study

Usability dimension is defined as how far the system is simple to use and structured properly [39]. The service is easy to use and easy to search for desired products. The process of Shopping on Facebook is clear, understandable and user friendly.

\section{H.1 Usability in Facebook online shopping positively influences overall service quality.}

Reliability dimension refers to the ability to provide the service on time, accurately, dependably and up-to-date [40]. Sellers send products to customer as promised to customers on time, and should be free from errors [41]. Additionally, Sellers always update Facebook page with latest products, offers and discounts

\section{H.2 Reliability in Facebook online shopping positively influences overall service quality.}

Responsiveness is defined as the ability to deal effectively with complaints and timeliness of the service. At Facebook, sellers should be always ready to respond quickly to customers' requests and inquiries [42]. By using Facebook messenger feature sellers can interact directly and instantly with customers, who need help, for example reply to customers who ask for price and product details. The direct communication can help to build more confidence between sellers and customers. [38].

\section{H.3 Responsiveness in Facebook online shopping positively influences overall service quality.}

Trust is the extent to which the services are believed and trusted. Seller profile and reputation, and the personal traits of sellers all contribute to trust. Previous commercial activities and orders on Facebook can affect the seller's reputation. It was highlighted in [42] that trust depends on the quality of previous transactions and honesty. Earlier researches had confirmed that customers' intent to shop is highly dependent on the customers' perception of trust [43]. In the same paper it was indicated that users who trust social commerce sites are more likely to purchase on these platforms and raise the intent to shop.

\section{H.4 Trust in Facebook online shopping positively influences overall service quality.}

Empathy is the amount of caring, individualized attention the firm provides its customers [45]. In the context of Facebook, sellers should understand the specific needs of customers and give personal attention and care to them by replying customers' questions and conveyed their knowledge and recommendations to them [38].

\section{H.5 Empathy in Facebook online shopping positively influences overall service quality.}

Courtesy is defined as the politeness, respect, consideration and friendliness shown to the customers by the contact personnel. Sellers should be consistently courteous to customers and address their complaints in a friendly way [46]. 
International Journal of Managing Information Technology (IJMIT) Vol.12, No.3, August 2020

H.6 Courtesy in Facebook online shopping positively influences overall service quality.

Price is the extent to which the value of a product is reasonable. It was stated in [47] that price advantage and product differentiation raised customer intention to buy from online firms. Therefore, Prices and charges should be Reasonable in order to increase orders.

\section{H.7 Price in Facebook online shopping positively influences overall service quality.}

Security is the Degree to which the customer believes the system is safe and personal information is protected [48]. Customers should feel safe in the Facebook environment. The Facebook Messages feature can afford privacy between customers and sellers [49].

H.8 Security in Facebook online shopping positively influences overall service quality.

Customer satisfaction is a cumulative construct that is a function of service expectations and performance perceptions in any given period [50], [51]. Thus, service quality has a direct, positive relationship with customer satisfaction and this in turn may lead to increase the customer intent to buy [52], [53], [54] and [55].

H.9 Overall service quality with Facebook online shopping positively influences customer satisfaction.

H.10 Customer satisfaction with Facebook online shopping positively influences purchase intentions.

\section{RESEARCH METHODOLOGY}

An empirical study was conducted using a quantitative approach to test the relationship between the research model variables in this study, and also provided evidence to support, or work against, the research hypotheses [58].

\subsection{Questionnaire-based Survey design}

This study aims to measure the effect of service quality dimension on customer satisfaction on using social commerce. Therefore, this aim was translated into a series of questions, first part include demographic questions (gender, age, income, and education and occupation), daily time spent on Facebook and the frequency of doing shopping through Facebook page, and the second part include model questions. The questionnaire (see Table 1) contains 10 service quality constructs and total of 32 items (adapted from previous researches [24], [60], [19]) measuring the dimensions that were selected for this study based on the literature.

Table 1. Construct items questions

\begin{tabular}{|l|l|c|}
\hline Construct & Items & References \\
\hline \multirow{4}{*}{ Usability } & -Shopping on Facebook is user-friendly & \\
\cline { 2 - 2 } & -Shopping on Facebook is clear and understandable & [72], [73], \\
\cline { 2 - 3 } & -It is easy to search for desired products on Facebook & \\
\cline { 2 - 3 } & -It is easy to become skillful when do shopping on Facebook. & \\
\hline
\end{tabular}


International Journal of Managing Information Technology (IJMIT) Vol.12, No.3, August 2020

\begin{tabular}{|c|c|c|}
\hline \multirow{5}{*}{ Reliability } & -Sellers in Facebook deliver their service as promised to customers on time & \multirow{5}{*}{$\begin{array}{c}{[68],[73],} \\
{[75]}\end{array}$} \\
\hline & -Sellers in Facebook perform the service right the first time & \\
\hline & -Sellers in Facebook deliver the order at the time it promises to do so. & \\
\hline & $\begin{array}{l}\text {-Sellers in Facebook always update the page with latest products, offers and } \\
\text { discounts }\end{array}$ & \\
\hline & -Sellers in Facebook deliver errors-free orders as promised to customers & \\
\hline \multirow{5}{*}{ Responsiveness } & $\begin{array}{l}\text {-Sellers in Facebook are always ready to handle our customers' requests and } \\
\text { needs }\end{array}$ & \multirow{5}{*}[24]{,$[76]$} \\
\hline & -Sellers in Facebook are never too busy to respond to customers' requests & \\
\hline & -Sellers in Facebook Respond quickly to customer Requests & \\
\hline & -Sellers in Facebook show Sincere desire to Solve Problems for Customers & \\
\hline & $\begin{array}{l}\text {-Sellers in Facebook provide Alternative Communication Channels (Phone, } \\
\text { SMS, Messenger, WhatsApp) with customers }\end{array}$ & \\
\hline \multirow{3}{*}{ Trust } & -Sellers in Facebook are in general honest. & \multirow{3}{*}{$\begin{array}{c}{[76],[77]} \\
{[78]}\end{array}$} \\
\hline & -Sellers in Facebook are in general trustworthy. & \\
\hline & $\begin{array}{l}\text {-Sellers in Facebook guarantee to refund for any error in the order or the } \\
\text { product }\end{array}$ & \\
\hline \multirow{3}{*}{ Empathy } & -Sellers in Facebook understand the specific needs of customers & \multirow{3}{*}{ [79],[80] } \\
\hline & -Sellers in Facebook Listen to the customer & \\
\hline & -Sellers in Facebook give Personal attention to customers & \\
\hline \multirow{4}{*}{ Courtesy } & -Sellers in Facebook address complaints friendly & \multirow{4}{*}{ [81] } \\
\hline & -Sellers in Facebook are consistently very polite with customers & \\
\hline & -Sellers in Facebook respond to customers' requests and demands & \\
\hline & -Sellers in Facebook encourage them to purchase & \\
\hline \multirow{2}{*}{ Price } & -Prices of products on Facebook and Fees of delivery are reasonable & \multirow{2}{*}[82]{} \\
\hline & -Sellers in Facebook explain charges to customers & \\
\hline \multirow{2}{*}{ Security } & -It is secured to make shopping on Facebook & \multirow{2}{*}{ [68], [83] } \\
\hline & -Sellers in Facebook Keep customer 's personal data safe & \\
\hline $\begin{array}{l}\text { Overall service } \\
\text { quality }\end{array}$ & $\begin{array}{l}\text {-My overall opinion of the services provided by Sellers in Facebook is very } \\
\text { good }\end{array}$ & [69] \\
\hline $\begin{array}{l}\text { Customer } \\
\text { Satisfaction }\end{array}$ & -Overall, I am satisfied with Facebook shopping online experience & [75] \\
\hline \multirow{2}{*}{ Intention to buy } & -I plan to make shopping from Facebook in the next 30 days & \multirow{2}{*}{ [69] } \\
\hline & -I strongly recommend others to make shopping through Facebook & \\
\hline
\end{tabular}




\subsection{Development of Measurement Scale}

Likert scales are treated as interval scales, and they are the most frequently used scales in information systems research (Sekaran, 2003). From the Likert scales, the five and the sevenpoint scales are the most commonly used scales (Malhotra and Peterson, 2006). However, in this research all measurements were evaluated using a 5-point Likert scale ranging from 1 (strongly disagree) to 5 (strongly agree) because it is easier for the participants to read out the complete list of scale descriptors.

\subsection{Evaluating the Questionnaire Reliability}

This research used the Cronbach alpha test to measure internal reliability. It is most commonly used when you have multiple Likert questions in a survey/questionnaire that form a scale and you wish to determine if the scale is reliable. The reliability function in the SPSS was used to test the internal consistency for the items of each construct's measure in the survey. A review of the literature defines an acceptable level of internal reliability as a computed alpha coefficient that varies between a perfect internal reliability (1) and no internal reliability (0). Hair et al. (1995) suggest 0.70 coefficients as good internal reliability, but Pallant (2001) argues that 0.60 coefficient is a good internal reliability. Four levels of reliability are suggested by Hinton et al. (2004), as low (0.50 and below), high moderate (0.50-0.70), high (0.70-0.90) and excellent $(0.90$ and above).

The results shows adequate reliability levels in all SERVQUAL dimensions used as follows: Usability (0.653), Reliability (0.775), responsiveness (0.678), trust (0.773), empathy (0.795), Courtesy (0.784), Price (0.656), and Security (0.613) and also overall consistency of the data (0.868).

\subsection{Data Collection}

Structured questionnaires were distributed over respondents who make shopping through Facebook. Data collected was statistically analyzed using frequencies, cross tabulations and Regression.

The questionnaire was constructed using Google forms and was distributed electronically. The link was shared and posted on a popular online shopping Facebook page in Egypt for two weeks in mid of April 2020. The selected online Facebook page was created in 2012 and the number of members of this page exceeds 19 thousand members. 252 responses were collected from which 243 were valid, and the others were removed due to the presence of incomplete questions. Most of the questions in the questionnaire were adapted from earlier researches as mentioned before. However a number of questions were self-developed solely for the purpose of this research to address important concepts, which were not addressed in previous studies.

\section{RESEARCH RESUlTS}

\subsection{Demographic Analysis}

$95.1 \%$ of the respondents were women. Nearly, $58 \%$ of the respondents had completed their postgraduate studies, and $25.9 \%$ completed their university education. Approximately, $45.7 \%$ of the respondents were between 41 and 55 years old. Most of respondents are salaried employee $(70.4 \%)$. The majority of respondents have a monthly income within the range of 5,000 to 15,000 EGP (44.4\%) followed by those with a monthly income within the range of EGP 1000 to 5000 
International Journal of Managing Information Technology (IJMIT) Vol.12, No.3, August 2020

$(29.8 \%)$. Moreover, the majority spends from 2 to 5 hours daily surfing the Facebook (43.2\%). While, $61.7 \%$ of the sample conducted shopping through Facebook at least 1 to 5 times (see Table2).

Table 2. Respondents' Characteristics

\begin{tabular}{|c|c|c|}
\hline Measure & Items & $\%$ \\
\hline \multirow{2}{*}{ Gender } & Male & 4.9 \\
\hline & Female & 95.1 \\
\hline \multirow{5}{*}{$\begin{array}{l}\text { Times per month purchased } \\
\text { products from Facebook }\end{array}$} & Never & 24.7 \\
\hline & $1-5$ & 61.7 \\
\hline & $5-10$ & 6.2 \\
\hline & $10-20$ & 3.7 \\
\hline & Over 20 & 3.7 \\
\hline \multirow{4}{*}{ Age } & Below 25 & 25.9 \\
\hline & $26-40$ & 24.7 \\
\hline & $41-55$ & 45.7 \\
\hline & Over 55 & 3.7 \\
\hline \multirow{4}{*}{ Education } & Post graduate & 58 \\
\hline & Graduate & 25.9 \\
\hline & Average qualification & 9.9 \\
\hline & No qualification & 6.2 \\
\hline \multirow{3}{*}{ Occupation } & Student & 17.3 \\
\hline & Salaried employee & 70.4 \\
\hline & Retired & 12.3 \\
\hline \multirow{4}{*}{ Monthly Income } & Less than 1000 EGP & 6.2 \\
\hline & $1,000-5,000 \mathrm{EGP}$ & 29.8 \\
\hline & 5,000 -15,000 EGP & 44.4 \\
\hline & More than 15,000 EGP & 19.8 \\
\hline \multirow{3}{*}{$\begin{array}{l}\text { Average time spent on } \\
\text { Facebook }\end{array}$} & $\leq 2$ hour/day & 38.3 \\
\hline & 2-5 hour/day & 43.2 \\
\hline & $\geq 5$ hour/day & 18.5 \\
\hline
\end{tabular}




\subsection{Testing the Hypotheses}

SPSS was used in testing the model. Statistical Correlation test has been applied to find the direction and strength of relationship between independent and dependent variables/factors. Correlation provided the type and direction of inter-relationship and intensity of relationship among factors [56].

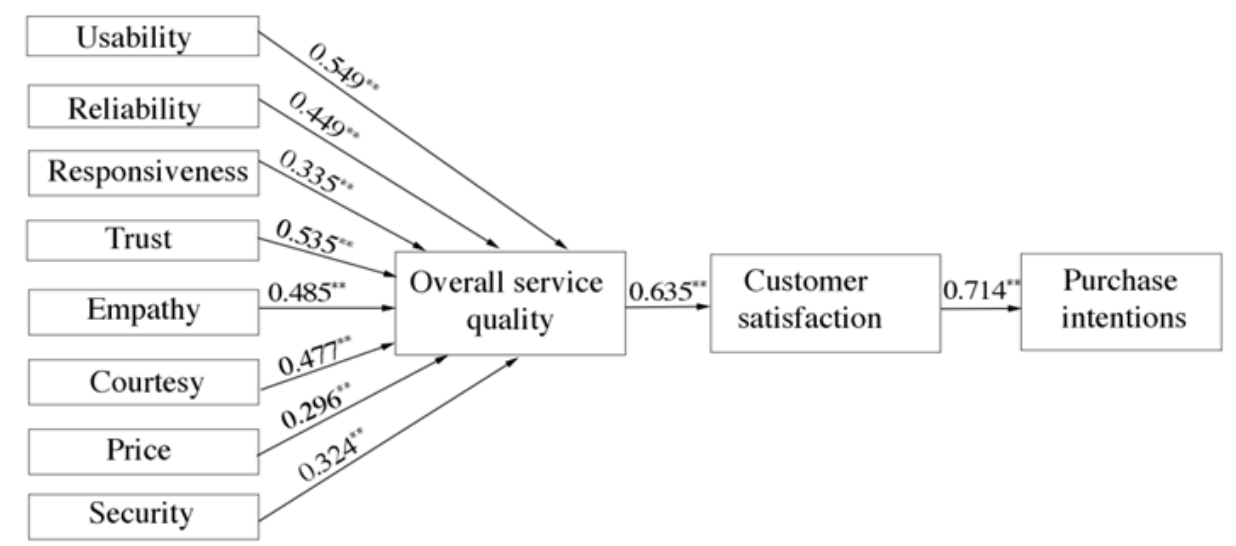

Figure 2. Results of the research frame work of this study (Note:**p<0.01)

The results as shown in (Figure 2) indicated that all hypotheses are accepted as following: Usability has strong positive influence on Overall service quality $(\mathrm{H} 1, \mathrm{R}=0.549, \mathrm{p}<0.01)$. Reliability has strong positive influence on Overall service quality $(\mathrm{H} 2, \mathrm{R}=0.449, \mathrm{p}<0.01)$, Responsiveness has strong positive influence on Overall service quality $(\mathrm{H} 3, \mathrm{R}=0.335, \mathrm{p}<0.01)$, Trust has strong positive influence on Overall service quality $(\mathrm{H} 4, \mathrm{R}=0.535, \mathrm{p}<0.01)$, Empathy has strong positive influence on Overall service quality $(\mathrm{H} 5, \mathrm{R}=0.485, \mathrm{p}<0.01)$, Courtesy has strong positive influence on Overall service quality $(\mathrm{H} 6, \mathrm{R}=0.477, \mathrm{p}<0.01)$, Price has strong positive influence on Overall service quality $(\mathrm{H} 7, \mathrm{R}=0.296, \mathrm{p}<0.01)$ and Security has strong positive influence on Overall service quality $(\mathrm{H} 8, \mathrm{R}=0.324, \mathrm{p}<0.01)$. Additionally, the results showed that usability has the most positive effect on the overall service quality dimension with $\mathrm{R}=0.549$, followed by trust dimension $(\mathrm{R}=0.535)$. While, the price dimension has the least effect on overall service quality dimension $(R=0.296)$.

The overall service quality construct showed a strong positive influence to customer satisfaction $(\mathrm{H} 9, \mathrm{R}=0.635, \mathrm{p}<0.01)$. In addition, the Customer satisfaction also has a strong positive influence to purchase intentions through Facebook $(\mathrm{H} 10, \mathrm{R}=0.714, \mathrm{p}<0.01)$.

\section{DisCUSSION}

The aim of this research is to investigate the relationship between the e-services quality dimensions, customer satisfaction and customer purchase intentions from s-commerce customer point of view.

According to the results and in consistent with previous findings of [61], [62], Usability (H1) is the most prominent dependent variable, and has the highest significant positive effect on overall service quality $(\mathrm{R}=0.549$ with $\mathrm{p}<0.01)$ which means customers like to shop on Facebook due to the usability of the platform. If sellers want to increase the service quality of their groups or pages, they should put the products in a way to be easy for customers to search them. 
International Journal of Managing Information Technology (IJMIT) Vol.12, No.3, August 2020

Furthermore, trust dimension (H4) is considered as an important factor and has also a strong positive significant relationship with service quality dimension, with high correlation effect. This result is similar to the results of other study [61]. Consequently, to gain the trust of customers, Facebook sellers should take into consideration many factors such as honesty and after-sales support. They should provide quick response to problems and guarantee to make refund for any error in the order or in the product.

Additionally, empathy, courtesy and reliability dimensions were also significantly and positively correlated with overall quality dimension with the values of $\mathrm{R}=0.485,0.477$ and 0.449 with $\mathrm{p}$ $<0.01$ respectively. These results mean that sellers should address customer complaints in a friendly way, respond to customer requests and their specific needs, deliver error-free order on time as promised and update the page with latest products and offers to increase customer satisfaction. The results of this study confirm those obtained in [62], [63], [64], [65] and [66].

While, the study showed that Responsiveness (H3) which is compatible with [62], [63], and [65] has positive significant relationship on service quality. Sellers must have the ability to deal effectively with customer complaints and timeliness of the service by responding quickly to customers' requests and inquiries in order to increase the service quality of the page or group.

On the other hand, Security (H8), and Price (H7) have the lowest positive significant relationship effect on service quality. This is because most of respondents make shopping on Facebook on a regular base ( 1 to 5 times per month). They find it a secure way to shop as they payment method used is cash on delivery so if the product is defected or not authentic customer will not take it. Moreover, buyers found that prices are appropriate as many sellers explain the price charges and the delivery fees to their customers comparable to online website.

In addition, the Overall service quality variable (H9) is significantly positively affect the Customer satisfaction dimension (H10) which in turn positively affects the customer intention to buy on Facebook. As customer satisfaction has the highest impact on intention to buy then, the better the quality of service offered the more the customer is satisfied and will do more shopping on Facebook.

\section{CONCluSiONS AND Limitations}

Due to the increase in the number of Facebook users especially in Egypt, new business opportunities such as Social Commerce have emerged. Sellers on Facebook can sell products on their own pages or groups to members who can then interact directly with the seller, to ask for product details, price and delivery method. Social media facilitates the interactions among trading parties. This research provides a conceptual framework using service quality dimensions that are vital to understand social commerce on Facebook to be able to reach customers' satisfaction and increase customers' purchases. A good understanding of the service quality attributes that customers use to judge is necessary for sellers on Facebook to be able to monitor and enhance their service performance and improve the overall service quality.

This research explored the service quality dimensions in B2C Facebook commerce in Egypt. The eight service quality dimensions used are usability, reliability, responsiveness, trust, empathy, courtesy, price and security were proposed. The research hypotheses were all accepted. The results revealed that usability and trust $(0.549$ and 0.535 respectively) were the highest dimensions that positively influence the overall service quality variable. Empathy and courtesy dimensions also showed great importance with 0.485 and 0.477 respectively. Likewise, reliability 
International Journal of Managing Information Technology (IJMIT) Vol.12, No.3, August 2020

dimension exhibited large influence too with 0.449. Nevertheless, Price dimension has the lowest effect the overall service quality variable with $\mathrm{R}=0.296$.

To conclude, in order to increase customer purchase rate though Facebook, there are many implications for sellers in the result of this study. First, Customers found that Facebook is easy to use to shop online therefore; sellers should display their products in a friendly way to be easy for customer to search. Additionally, customers believe that the sellers' credibility (honesty) has a great effect on the overall service quality variable. As well as, how old the page is, the active status and the number of positive comments are key indicators of seller's credibility. On the other hand, sellers should show respect to customers, give individual attention to them, resolve complaints politely, deliver orders accurately and on time, and offer an after-sale support.

Finally, there are a number of limitations in this research. First, the study is conducted on only one social media platform (i.e, Facebook). Further investigation of several platforms such as Instagram is recommended. Moreover, the sample was limited and the data was collected from one popular online shopping Facebook page in Egypt. Therefore, in order to generalize the findings, the sample size should be collected from more pages and more respondents. Finally, a qualitative study is also recommended in this context to examine more closely the service quality dimensions and their effects on customer satisfaction.

\section{REFERENCES}

[1] S. Hsu, Q. Fang, W.Chien-Chih, and H.Hsin-Ling, 'Evaluation of Service Quality in Facebook-Based Group-Buying.', Electronic Commerce Research and Applications Vol.28, pp.30-36, 2018.

[2] H. Alfawareh, S. Jusoh S. 'The Use and Effects of Smartphones in Higher Education', International Journal of Interactive Mobile Technologies(iJIM), Vol. 11, No. 6, pp.103-111, 2017.

[3] A. Leeraphong, P. Mahatanankoon, and B. Papasratorn, 'Evaluating Electronic Service Quality for C2C Social Commerce in Thailand: A Pilot Study', Eleventh International Conference on Digital Information Management(ICDIM), Porto, Portugal, pp.191-96, 2016.

[4] Y. Bai, Y. Zhong, and D.Yi-Fan D, 'Effect of Social Commerce Factors on User Purchase Behavior: An Empirical Investigation from Renren.Com.' International Journal of Information Management, Vol. 35, No. 5, pp.538-50, 2015.

[5] A. Marra, and P. Antonelli, 'Social commerce: a taxonomy and cross-component investigation of business practices and technological choices', Int.J.Electronic Business, Vol. 14, No. 4, pp.352-370, 2018.

[6] HootSuite, 'Global Report (Q4 Update) (2019) ', https://hootsuite.com/pages/digital-in-2019 (Accessed, January, 2020).

[7] Payfort Blog, 'Welcome to State of Payments 2017', https://www.payfort.com/blog/2017/10/16/welcome-to-state-of-payments-2017/ (Accessed, January, 2020)

[8] M. Pakurár, H. Haddad , J. Nagy, J. Popp, and J. Oláh, 'The Service Quality Dimensions that Affect Customer Satisfaction in the Jordanian Banking Sector', Sustainability journal, Vol.11, No.4, pp.1113-1137, 2019.

[9] Y. Zhang, S. Lu, S. Gupta, and L. Zhao, 'What motivates customers to participate in social commerce? The impact of technological environments and virtual customer experiences', Information \&Management, Vol. 51, No.8, pp. 1017-1030, 2014.

[10] Z. Zhang, M. Ben Youcef, and J. Zhao, (2016), 'Building brand loyalty in social commerce: the case of brand micro blogs', Electronic Commerce Research and Applications, Vol.15, pp.14-25,2016.

[11] Statistica, 'Distribution of Facebook users in Egypt as of December 2019, by age group', https://www.statista.com/statistics/1028451/facebook-user-share-in-egypt-by-age/ (Accessed, January, 2020)

[12] Import-Export Solutions, https://import-export.societegenerale.fr/en/country/egypt/ecommerce (Accessed, January, 2020) 
International Journal of Managing Information Technology (IJMIT) Vol.12, No.3, August 2020

[13] Minister of Communications and Information Technology Egypt (MCIT), 'ICT Policy Review: $\begin{array}{lllll}\text { National E-Commerce } & \text { Strategy } & \text { for } & \text { Egypt', } & 2018\end{array}$ http://www.mcit.gov.eg/Upcont/Documents/Publications 1532018000 e-Commerce-StrategyMarch2018.pdf (Accessed, January, 2020).

[14] Nielsen Company, 'How digital influences how we shop around the world'2012 http://fi.nielsen.com/site/documents/NielsenGlobalDigitalShoppingReportAugus $\quad$ t2012.pdf (Accessed, January, 2020).

[15] K. Ishii, 'A comparative study between Japanese, US, Taiwanese, and Chinese social networking site users. In: Tellerino, A.S. (Ed.), Between the Public and Private in Mobile Communication', Routledge, London, UK, 2017

[16] Digital Marketing Statistics \& Metrics, 'Social Media Users in Egypt: Facebook Insights and Usage in Egypt, 2018', https:/www.digitalmarketingcommunity.com/indicators/facebook-insights-usage-inegypt-2018/ (Accessed, January, 2020)

[17] B. Yahia, N. Al-Neama, and L. Kerbache, 'Investigating the Drivers for Social Commerce in Social Media Platforms: Importance of Trust, Social Support and the Platform Perceived Usage', Journal of Retailing and Consumer Services, Vol. 41 pp. 11-19, 2018.

[18] Y. Li, 'How Social Commerce Constructs Influence Customers' Social Shopping Intention? An Empirical Study of a Social Commerce Website', Technological Forecasting and SocialChange, Vol.144, pp.282-94, 2019.

[19] A. Zeithaml, A. Parasuraman, and A. Malhotra, 'A Conceptual Framework for Understanding eService Quality: Implications for Future Research and Managerial Practice’, MSIMonograph, 2000

[20] S. Wang, Y. Wang, and Y. Shee, 'Measuring e-learning systems success in an organizational context: Scale development and validation', Computers in Human Behavior, Vol.23, No.4, pp.1792-1808, 2007

[21] A. Parasuraman, A. Zeithaml, and L. Berry, 'SERVQUAL: a multiple-item scale for measuring consumer perceptions of service quality', Journal of Retailing, Vol. 64, No. 1, pp. 12-40, 1988

[22] C .Mehta, K. Lalwani, and L. Han, S.L, 'Service quality in retailing: relative efficiency of alternative measurement scales for different product-service environments', International Journal of Retail \& Distribution Management, Vol. 28, No.2, pp.62-72, 2000

[23] R. Saravanan, and P. Rao, (2007), 'Measurement of service quality from the customer's perspectivean empirical study', Total Quality Management and Business Excellence, Vo.18, No.4, pp.435-449, 2007

[24] A. Parasuraman, A. Zeithaml, and A. Malhotra, 'E-S-QUAL: a multiple-item scale for assessing electronic service quality', Journal of Service Research, Vol. 7 No. 3, pp. 213-33, 2005

[25] R. Casidy R, 'Linking brand orientation with service quality, satisfaction, and positive word-ofmouth: Evidence from the Higher Education Sector', Journal of Nonprofit \& Public Sector Marketing. Vol. 26, No.2, pp.142-16, 2014.

[26] S. Chong, and K. Ahmed, 'Student motivation and the 'feel good' factor: an empirical examination of motivational predictors of university service quality evaluation', Studies in Higher Education. Vol. 40, No.1, pp.158-177, 2015

[27] B. Palese, B, and A. Usai, 'The Relative Importance of Service Quality Dimensions in E-Commerce Experiences', International Journal of Information Management Vol.40, 132-140, 2018

[28] Z. Huang, Y. Luo, and D. Wang, 'Online customer service quality of online shopping: evidence from Dangdang.com', Cluster Computing Vol. 22, No.6, pp. 15285-15293, 2019.

[29] N. Hafiz, and A. Alam, (2016), 'Applying SERVQUAL Model to Measure Online Customer Satisfaction in Package Delivery Services', Studia UBB Negotia, Vol. 61, No. 4, pp. 121-136, 2016.

[30] L. Jiang, J. Minjoon , and Y. Zhilin, 'Customer-Perceived Value and Loyalty: How Do Key Service Quality Dimensions Matter in the Context of B2C e-Commerce?', Service Business, Vol.10, No. 2, pp. 301-17, 2016.

[31] Z. Yang, C. Shaohan, Z. Zheng, and Z. Nan Z, 'Development and Validation of an Instrument to Measure User Perceived Service Quality of Information Presenting Web Portals', Information \&Management, Vol. 42, No. 4, pp. 575-89, 2005.

[32] Y. Lin, J. Luo, S. Cai , and K. Rong, 'Exploring the service quality in the ecommerce context: a triadic view', Industrial Management and DataSystems, Vol.116, No.3, pp.388 - 415, 2016. 
International Journal of Managing Information Technology (IJMIT) Vol.12, No.3, August 2020

[33] A. Shahin, and M. Pourhamidi, 'Service TRIZ: An approach for service quality design- with a case study in the hospitality industry', International Journal of Business Innovation and Research, Vol.5, No.4, pp.291-308, 2011

[34] H. Lee, Y. Lee, and D. Yoo, 'The determinants of perceived service quality and its relationship with satisfaction', Journal of services marketing, Vol. 14, No.3, pp.217-231, 2000

[35] A. Salameh, and S. Hassan, 'Measuring service quality in m-commerce context: a conceptual model', International Journal of Scientific and Research Publications, Vol. 5 No. 3, pp.1-9, 2015

[36] K. Biswas, M. Nusari, and A. Ghosh, 'The Influence of Website Service Quality on Customer Satisfaction Towards Online Shopping: The Mediating Role of Confirmation of Expectation', InternationalJournalofManagementScienceandBusinessAdministration, Vol. 5, No. 6, pp. 7-14, 2019.

[37] A. Qusef, C. Baker, and M. Muhanna, 'Social Commerce Quality Service from Customer Persective', International Conference on Engineering \& MIS(ICEMIS), Monastir, Tunisia, pp.1-5, 2017

[38] A. Leeraphong, P. Mahatanankoon , and B. Papasratorn , 'Evaluating Electronic Service Quality for C2C Social Commerce in Thailand: A EleventhInternationalConferenceonDigitalInformationManagement(ICDIM), Porto, Portugal, pp.191-96, 2016.

[39] W. Hsu, Q. Fang, W. Chien-Chih, and H. Hsin-Ling, 'Evaluation of Service Quality in FacebookBased Group-Buying.', Electronic Commerce Research and Applications Vol.28, pp.30- 36, 2018

[40] A. Parasuraman, A. Zeithaml, and L. Berry, 'A conceptual model of service quality and its implications for future research', JournalofMarketing, Vol. 49, No. 4, pp.41-50, 1985.

[41] S. Janita and J. Miranda, 'Exploring service quality dimensions in b2b emarketplaces', Journal of Electronic Commerce Research, Vol. 14, No.4, pp. 363, 2013.

[42] J. Strader and N. Ramaswami , 'The value of seller trustworthiness in C2C online markets', Communications of the ACM, Vol. 45, pp. 45- 49, 2002.

[43] M. Kang and P. Johnson, 'How does social commerce work for apparel shopping? Apparel social eshopping with social network storefronts',J.Cust.Behav. Vol. 12 , No.1, pp.53-72, 2013.

[44] S. Kim and H. Park, 'Effects of various characteristics of social commerce (s-commerce) on consumers' trust and trust performance', International Journal of Information Management, Vol. 33, No.2, pp. 318-332, 2013.

[45] E. Benjamin, 'Correlates of Customer Loyalty to Their Bank: A Case Study in Nigeria', International Journal of Bank Marketing, Vol. 24, No. 7, pp. 494-508, 2006.

[46] Z. Yang and X. Fang, 'Online service quality dimensions and their relationships with satisfaction: A content analysis of customer reviews of securities brokerage services', International Journal of Service Industry Management, Vol. 15,No. 3, pp. 302-326, 2004.

[47] H. Oh, Yoon, and Y. Lee, 'An empirical study on the determinants of trust and purchasing intention in online shopping', KoreaInd.Econ.Assoc, Vol.19, No.1, pp.205-224, 2006.

[48] R.Ladhari, R. Ladhari, and M. Morales, 'Bank service quality: comparing Canadian and Tunisian customer perceptions', International Journal of Bank Marketing, Vol. 29, No. 3, pp. 224-246, 2011.

[49] V. Verma, and E. Duggal, 'Retail service quality in India: construct exploration and measure development', South Asian Journal of Global Business Research, Vol. 4 No. 1, pp. 129-148, 2015.

[50] A. AbuElSamen, M. Akroush, and B. AbuLail,'MobileSERVQUAL:Acomparative analysisofcustomers'andmanagers'perceptions',International Journal of Quality \& Reliability Management, Vol.30No.4,pp.403-425, 2013.

[51] B. Lin, and $\mathrm{Y}$. $\mathrm{Ku}$,'The influences of service quality of online or derandelectronic wordofmouthonpricesensitivityusingloyaltyasamediatingvariable',Int.J.ElectronicBusiness, Vol.12, No .3,pp.215-24, 2015

[52] F. Lai, M. Griffin, and J. Babin, ' How quality, value, image, and satisfaction create loyaltyata Chinese telecom', Journal of Business Research,Vol.62,No.10,pp.980-986, 2008

[53] E. Dahiy at, N. Akroush, and N. Abu-Lail, 'An integrated model of perceived service quality and customer loyalty: an empirical examination of the mediation effects of customer satisfaction and customer trust', International Journal Services and Operations Management, Vol. 9 No. 4, pp. 453490, 2011

[54] N. Kassim, and A. Abdullah, 'The effect of perceived service quality dimensions on customer satisfaction, trust, and loyalty in e-commerce settings', Asia Pacific Journal of Marketing and Logistics, Vol. 22 No. 3, pp. 351-371, 2010 
International Journal of Managing Information Technology (IJMIT) Vol.12, No.3, August 2020

[55] J. Carlson, and A. O’Cass, 'Developing a framework for understanding e-service quality, its antecedents, consequences, and mediators', Managing Service Quality, Vol. 21 No. 3, pp. 264-286, 2011

[56] C. Cronk, 'How to use SPSS', CA Pyrczk Publishing, 2019.

[57] U. Sekaran, 'Research methods for business: a skill building approach', Singapore: John Willey \& Sonsed:In, 2000.

[58] O. Abdul Kadir, "The Influence of Social Commerce Factors on Customer Intention to Purchase," Asian Themes in Social Sciences Research, Knowledge Press, vol. 3(1), pages 1-10, 2019.

[59] F. Belanger, and L. Carter, 'Trust and risk in e-government adoption', The Journal of Strategic Information Systems, vol. 17, no. 2, pp. 165-76, 2008.

[60] D. Ribbink, R. van Riel, V. Liljander, and S. Streukens, "Comfort your online customer: quality, trust and loyalty on the internet", Managing Service Quality, Vol. 14 No. 4, pp. 446-456, 2004.

[61] M.Bhuvana, S.Vasantha, 'Assessment of rural citizens satisfaction on the service quality of common service centers (cscs) of e-governance', Journal of Critical Reviews, Vol 7, Issue 5, 2020.

[62] L. Yan, S. Huping, 'Service quality, perceived value, and citizens' continuous-use intention regarding e-government: Empirical evidence from China', Information \& Management Journal, Vol 57, Issue 3, 2020.

[63] M. Emad, ' The Effect of Service Quality on Customers' Satisfaction in Mobile Phone Services in the UAE’, Transnational Marketing Journal, Vol. 8 No. 1, 2020.

[64] M. Robert, 'Effect of service quality on students' satisfaction in tanzania higher education', Business Education Journal, Vol. 2, Issue 2, 2019.

[65] L. Chen, Y. Li, C. Liu, 'How airline service quality determines the quantity of repurchase intention Mediate and moderate effects of brand quality and perceived value', Journal of Air Transport Management, Vol. 75, Pages 185-197, 2019.

[66] J. Minjoon, S.Palacios, 'Examining the key dimensions of mobile banking service quality: an exploratory study', International Journal of Bank Marketing, 2015.

[67] K. Mai Ngoc, and D. Ngo, 'The Factors Affecting Customer Satisfaction and Customer Loyalty - A Study of Local Taxi Companies in Ho Chi Minh City, Vietnam', International Journal of Innovation, Management and Technology, Vol. 7, No. 5, 2016.

[68] M. Wolfinbarger, M. Gilly, "eTailQ: Dimensionalizing, Measuring and Predicting E-tail Quality," Journal of Retailing, Vol. 79, No. 3: 183-198, 2003.

[69] F.Zhu,W. Wymer, I. Chen, I. "IT-based services and service quality inconsumer banking", International Journal of Service Industry Management, Vol. 13 No. 1,pp. 69-90, 2002.

[70] R. Rust, and A. Zahorik, "Customer satisfaction, customer retention, and market share",Journal of Retailing, Vol. 69 No. 2, pp. 193-215, 1993

[71] J. Llusar, C. Zornoza, and A. Tena, "Measuring the relationship between firm perceived quality and customer satisfaction and its influence on purchase intentions",Total Quality Management, Vol. 12 No. 6, pp. 719-34, 2001.

[72] D.Ribbink, R. van Riel, V. Liljander, and S. Streukens, "Comfort your online customer: quality, trust and loyalty on the internet", Managing Service Quality, Vol. 14 No. 4, pp. 446-456, 2004.

[73] Z. Yang, M. Jun, and R. Peterson, "Measuring customer perceived online service quality: scale development and managerial implications". International Journal of Operations and Production Management,21(11),1149-1174,2004.

[74] Fassnacht, M. and I. Koese, "Quality of Electronic Services: Conceptualizing and Testing a Hierarchical Model,” Journal of Service Research, Vol. 9, No. 1: 19-37, 2006.

[75] S.Dahiyat, M. Akroush, and B. Abu-Lail,“An integrated model of perceived service quality and customer loyalty: an empirical examination of the mediation effects of customer satisfaction and customer trust", International Journal Services and Operations Management, Vol. 9 No. 4, pp. 453490, 2011.

[76] G. Lee, and H. Lin, "Customer perceptions of e-service quality in online shopping"International Journal of Retail and Distribution Management, 33(2), 161-176, 2005.

[77] J. Barnes, andT. Vidgen, "An integrative approach to the assessment of E-commerce quality",Journal of Electronic Commerce Research3(3), 114-127, 2002. 
International Journal of Managing Information Technology (IJMIT) Vol.12, No.3, August 2020

[78] S. Kim, and L. Stoel,, “Apparel retailers: website quality dimensions and satisfaction”,Journal of Retailing and Consumer Services, 11(2), 109-117, 2004.

[79] Y. Li, K. Tan, andM. Xi, "Measuring web-based service quality",Total Quality Management and Business Excellence, 13(5), 685-700, 2002.

[80] S. Gounaris, and S. Dimitriadis, "Assessing service quality on the web: evidence from business-toconsumer portals",Journal of Services Marketing, 17(4/5), 529-548, 2003.

[81] A. Shahin, and M. Pourhamidi, "Service TRIZ: An approach for service quality de- sign-with a case study in the hospitality industry", International Journal of Business Innovation and Research 5(4), 291-308, 2011.

[82] A. Shahin, E. BagheriIraj, and H. VaezShahrestani, "Developing house of quality by integrating top roof and side roof matrices and service TRIZ with a case study in banking services"The TQM Journal, 28(4), 597-612, 2016.

[83] C. Ranganathan, and S. Ganapathy, "Key dimensions of business-to-consumer web sites",Information \& Management, 39(6), 457-465, 2002.

\section{AUTHORS}

\section{Rehab ELBadrawy ,PHD}

She is an Assistant professor in Arab Academy for Science, Technology and Maritime Transport, Alexandria, Egypt. She has published many papers and articles in international conferences and journals in the e-commerce fields and in Industrial engineering and engineering management fields. She has ten years of experience in teaching and academic research.

\section{Sara EIKheshin, PHD}

She is an Assistant professor in Arab Academy for Science, Technology and Maritime Transport, Alexandria, Egypt. She has 20 years working experience in Business Information System department, her research interest is e-government, e-business, and database

\section{Nermine Essawy, PHD,}

She is an Assistant professor in Arab Academy for Science, Technology and Maritime Transport, Alexandria, Egypt. She has 23 years working experience in Business Information System department, her research interest is e-business and ecrm 